\title{
Optical and geochemical characterization of Upper Sinemurian (Lower Jurassic) fossil wood from the Lusitanian Basin (Portugal)
}

\author{
Ricardo L. Silva, ${ }^{1 *}$ Luís V. Duarte ${ }^{1,2}$ and Joẽo G. Mendonça Filho ${ }^{3}$ \\ ${ }^{1}$ IMAR-Centro do Mar e Ambiente, Largo Marquês de Pombal, 3000-272 Coimbra, Portugal \\ ${ }^{2}$ Departamento de Ciências da Terra, Faculdade de Ciências e Tecnologia, Universidade de Coimbra, \\ Largo Marquês de Pombal, 3000-272 Coimbra, Portugal \\ ${ }^{3}$ Departamento de Geologia, Instituto de Geociências, Centro de Ciências Matemáticas e da Natureza, \\ Universidade Federal do Rio de Janeiro, Cidade Universitária, CEP: 21949-900, Ilha do Fundão, Rio de Janeiro, Brazil
}

(Received November 13, 2012; Accepted July 2, 2013)

\begin{abstract}
It is hypothesized that carbon and nitrogen isotopic compositions $\left(\delta^{13} \mathrm{C}\right.$ and $\left.\delta^{15} \mathrm{~N}\right)$ of fossil wood fragments will provide useful information regarding conditions prior, during, and after deposition. Eleven fossil wood samples were collected from the Sinemurian-lowermost Pliensbachian marly hemipelagic deposits of the Água de Madeiros Formation at S. Pedro de Moel (Lusitanian Basin, Portugal), and analyzed using optical and geochemical methods to confidently determine their use in palaeoenvironmental studies.

Organic petrography observations show that the fossil wood samples contain a wide variety of particles mostly related to the phytoclast group, but also include resin impregnations, palynomorphs, and/or marine amorphous organic matter. A significant positive correlation between total carbon content and $\delta^{13} \mathrm{C}$ is observed (defined by 8 out of 11 samples), and most samples have high $\delta^{15} \mathrm{~N}$. These data suggest that isotopic compositions of the studied samples were severely affected by sedimentary and diagenetic processes (biological or related to early diagenesis and coalification). It is evident that various processes of alteration either acted on different samples of the studied stratigraphic interval, or occurred with different magnitudes. It is considered that future stable isotopic studies on fossil wood should involve detailed screening as presented in this study, to ensure a proper understanding of the biological (mostly biodegradation) or diagenetic processes affecting samples and their impact on the determined chemical proprieties.
\end{abstract}

Keywords: fossil wood, carbon and nitrogen stable isotopes, Sinemurian, Lusitanian Basin, Portugal

\section{INTRODUCTION}

It is often assumed that $\mathrm{C}$ and $\mathrm{N}$ isotopic composition of fossil wood can provide important information to enable the discrimination of certain environmental parameters, (such as $p \mathrm{CO}_{2}$, and water availability), or to distinguish between $\mathrm{C}_{3}$ and $\mathrm{C}_{4}$ precursors in post-Cretaceous sediments. Numerous studies conducted over the recent years have investigated $\delta^{13} \mathrm{C}$ of fossil wood and its significance in palaeoenvironmental studies (e.g., Gröcke, 2002; van Bergen and Poole, 2002; Robinson and Hesselbo, 2004; Bechtel et al., 2007, 2008; Diefendorf et $a l ., 2010)$. The emerging use for this kind of data is related to differentiating between discrete, short-lived geological intervals at a time when the carbon cycle was globally perturbed and affected both the atmospheric and oceanic carbon reservoirs (e.g., Hasegawa, 1997; Gröcke et al., 1999a; Hesselbo et al., 2007; Hesselbo and

\footnotetext{
*Corresponding author (e-mail: ricardo.cdv@gmail.com)

Copyright @ 2013 by The Geochemical Society of Japan.
}

Pieńkowski, 2011). It is assumed that when the $\delta^{13} \mathrm{C}$ record of both marine carbonates and fossil wood show a coupled trend, (reflecting the oceanic and atmospheric carbon reservoirs), it is an indication that there was a global perturbation of the carbon cycle.

However, the use of fossil wood isotopic data are related to two main assumptions: 1) that the $\delta^{13} \mathrm{C}$ of fossil wood reflects, to some extent, the $\delta^{13} \mathrm{C}$ of the atmosphere at the moment of tree growth; 2) although diagenesis has altered the original $\delta^{13} \mathrm{C}$ values, it is likely that through a given section all samples have undergone similar diagenetic changes. Although the first assumption may seem fairly reasonable, the second assumption raises concerns as it tends to ignore lithological constraints (e.g., Gröcke, 1998), the process of degradation associated with residence time in the continental and marine environments prior to deposition (e.g., Tyson, 1995), the early diagenetic/coalification processes (e.g., Suárez-Ruiz and Crelling, 2008), a shift in composition due to severe oxidation (including burning) (e.g., Czimczik et al., 2002) and the impact of these processes on the isotopic composition of fossil wood (e.g., Rimmer et al., 2006). In con- 
trast, $\delta^{15} \mathrm{~N}$ has been seldom used in fossil wood studies (e.g., Boudou et al., 1984; Gröcke et al., 1999b; Gröcke, 2002; Kanduč et al., 2005; Rimmer et al., 2006) and its application is mostly related to the discrimination of diagenetic and coalification processes.

The uppermost Sinemurian record of the western sector of the Lusitanian Basin (Portugal) is characterized by the presence of marine, organic-rich marl-limestone alternations rich in benthonic and nektonic macro- and microfauna (Duarte and Soares, 2002; Duarte et al., 2010, 2012) (Fig. 1). In addition, the series occasionally includes fossil wood remains, up to $1 \mathrm{~m}$ in length (Fig. 2). The aim of this work is to determine whether fossil wood samples from the Sinemurian-lowermost Pliensbachian Água de Madeiros Formation at S. Pedro de Moel can be confidently used in palaeoenvironmental studies. The methods used in this study were visual observation under transmitted white light (TWL) and using a fluorescence mode (FM), and elemental (carbon and nitrogen) and isotopic $\left[\delta^{13} \mathrm{C}_{(\mathrm{PDB})}\right.$ and $\left.\delta^{15} \mathrm{~N}_{(\mathrm{Air})}\right]$ geochemistry.

\section{GEOLOGICAL BACKGROUND}

S. Pedro de Moel is located on the Portuguese coast,
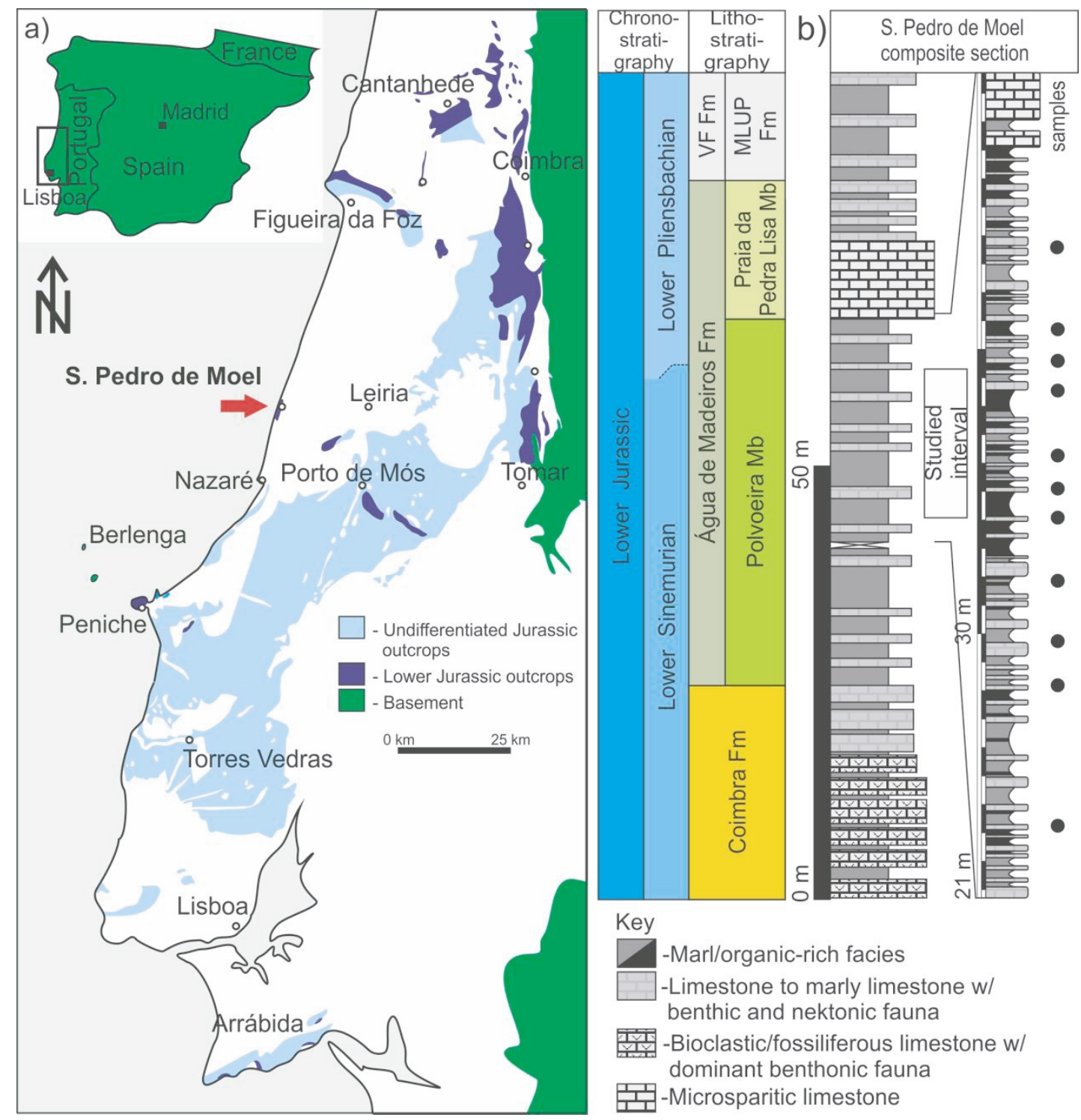

Fig. 1. a) Geological map of the main carbonate Jurassic outcrops in the Lusitanian Basin (modified from Duarte et al., 2010); b) synthetic composite log from the Polvoeira and Água de Madeiros reference sections of Sinemurian age at S. Pedro de Moel, Lusitanian Basin, Portugal (modified from Duarte et al., 2008; Azerêdo et al., 2010; chronostratigraphy from Comas-Rengifo et al., 2013). Detailed log based on Duarte et al. (2012). 
about $110 \mathrm{~km}$ north of Lisbon. The Lower Jurassic outcrops correspond to a thick succession of carbonate units belonging to the Coimbra, Água de Madeiros, Vale das Fontes, Lemede, and S. Gião formations (e.g., Duarte $e t$ al., 2008, 2012). This study focuses on the Polvoeira Member of the Água de Madeiros Formation, which crops out in two main locations south of S. Pedro de Moel; the Polvoeira and Água de Madeiros sections (Fig. 1). At this point, the Polvoeira Member corresponds to a marldominated unit, composed of marl-limestone alternations with the inclusion of several horizons of black shale (see Duarte et al., 2012 for a detailed description of this section). Detailed total organic carbon (TOC) and palynofacies studies have been conducted in the Água de Madeiros Formation of the S. Pedro de Moel region (e.g., Duarte et al., 2012; Poças Ribeiro et al., 2013), and ac-

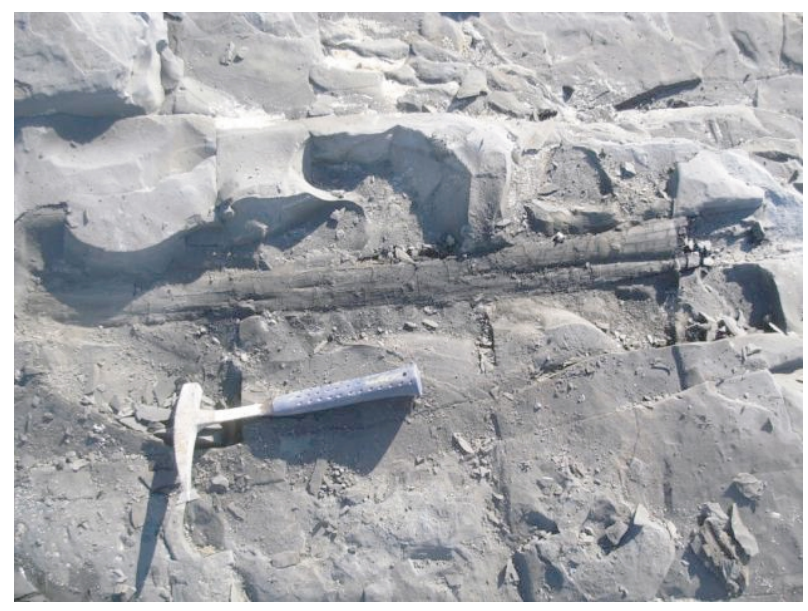

Fig. 2. Field view of the fossil wood sample V-OU224+0.3 of the Polvoeira Member, Água de Madeiros Formation at S. Pedro de Moel (Lusitanian Basin, Portugal). cording to such studies the kerogen assemblages of the Água de Madeiros Formation are dominated by amorphous organic matter (AOM), with some levels richer in palynomorphs or phytoclasts. According to Poças Ribeiro et al. (2013), the percentage of huminite reflectance in dispersed organic matter of the S. Pedro de Moel sections is around $0.45 \%\left(R_{\mathrm{o}}\right)$, suggesting that the studied section reached the final stages of humification and gelification (Sýkorová et al., 2005), in agreement with the $T_{\max }$ data from Duarte et al. (2012).

\section{Materials ANd Methods}

Based on detailed field work, 11 fossil wood samples were collected (Figs. 1(b) and 2) and prepared for organic petrography and elemental and isotopic analysis. Every effort was made to avoid contamination from the sedimentary matrix (rock). During sampling, a lustrous, black material resembling jet was discarded. The samples were inspected and any visibly altered parts were mechanically removed, along with the remaining sedimentary matrix.

After initial crushing, each sample was reacted with $\mathrm{HCl}(37 \%)$ to remove the carbonate fraction, then with HF (40\%) to remove the siliceous fraction. The sample was then divided into two subsets, one to be prepared according to the standard methodology for Palynofacies (Tyson, 1995) and the other to be analysed for total carbon (TC) and total nitrogen (TN) contents (wt. \%) and $\delta^{13} \mathrm{C}_{(\mathrm{PDB})}$ and $\delta^{15} \mathrm{~N}_{(\mathrm{Air})}(\%)$.

Organic petrographic observations were performed by optical microscopy using transmitted white light (TWL) and a fluorescence mode (FM), at the Palynofacies and Organic Facies Laboratory (LAFO) located at the Federal University of Rio de Janeiro (Brazil).

$\mathrm{TC}$ and TN contents and $\delta^{13} \mathrm{C}_{(\mathrm{PDB})}$ and $\delta^{15} \mathrm{~N}_{(\mathrm{Air})}$ were determined at the IMAR-CMA (at Coimbra University),

Table 1. Lithology, total carbon and nitrogen and stable isotopic data of fossil wood from the Upper Sinemurian Polvoeira Member (Água de Madeiros Formation) at S. Pedro de Moel

\begin{tabular}{lclccccc}
\hline Sample & Stratigraphic distance $(\mathrm{cm})$ & Lithological matrix & $\mathrm{TN}(\mathrm{wt} . \%)$ & $\mathrm{TC}(\mathrm{wt} . \%)$ & $\delta^{15} \mathrm{~N}_{(\mathrm{Air})}(\%)$ & $\delta^{13} \mathrm{C}_{(\mathrm{PDB})}(\%)$ & $\mathrm{C} / \mathrm{N}$ \\
\hline V-GP38 & 1949 & Marl & 1.4 & 67.7 & 4.5 & -25.4 & 50 \\
V-GP 26B & 1670 & Black shale & 1.0 & 68.9 & 4.6 & -23.9 & 68 \\
V-GP23T & 1565 & Limestone & 1.1 & 71.3 & 3.3 & -24.7 & 66 \\
V-GP18T & 1446 & Black shale & 1.0 & 71.5 & 3.5 & -24.5 & 75 \\
V-GP 7B & 1210 & Black shale & 0.9 & 66.7 & 4.8 & -22.6 & 74 \\
V-GP2T & 1112 & Marl & 0.3 & 87.6 & 0.9 & -22.8 & 280 \\
V-OU224+0.3 & 1025 & Marl & 0.9 & 73.4 & 4.2 & -24.1 & 81 \\
V-OU215B & 798 & Marl & 0.9 & 72.9 & 5.2 & -24.1 & 77 \\
V-OU208B & 592 & Marly limestone & 0.9 & 72.8 & 4.5 & -24.4 & 78 \\
V-OU201 & 449 & Marly limestone & 1.3 & 68.8 & 3.7 & -25.3 & 51 \\
V-OU176 & 0 & Marly limestone & 1.3 & 73.8 & 4.7 & -22.9 & 57 \\
\hline
\end{tabular}

Note: TN, total nitrogen; TC, total carbon; $C / N$, total carbon/total nitrogen. 

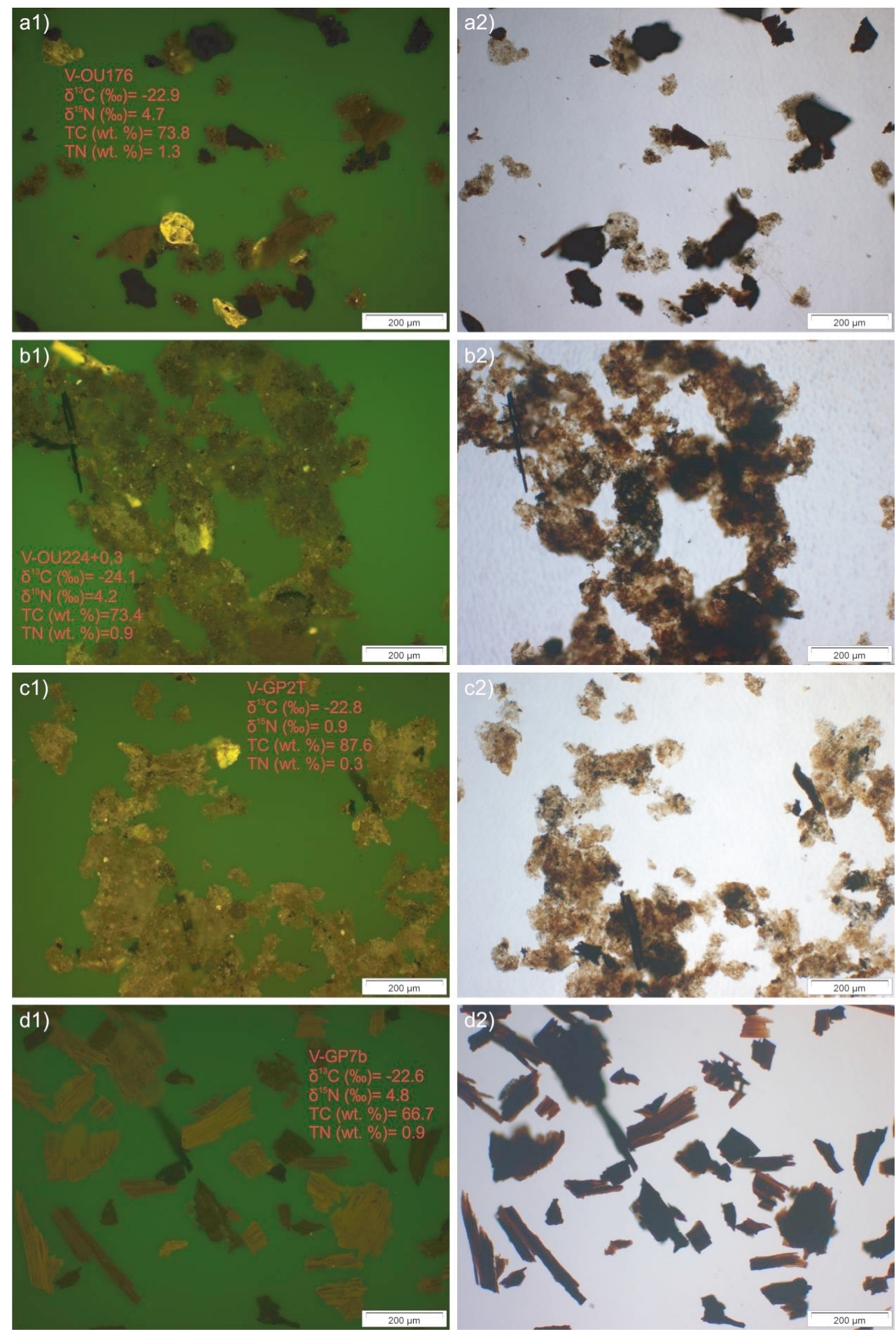

Fig. 3. Fossil wood characteristics in transmitted white light (al, bl, cl, d1, e1,fl, gl, hl); and fluorescent mode (a2, b2, c2, d2, $e 2, f 2, g 2, h 2)$; and isotopic and elemental data from the Polvoeira Member (Late Sinemurian) of S. Pedro de Moel.

using dynamic flash combustion. Around $0.5 \mathrm{mg}$ of previously dried (at room temperature) and ground material was placed in tin cups and analysed using a Flash EA, coupled with a Thermo Electron Delta V Advantage mass spectrometer. Internal precision is better than $0.1 \%$ for $\delta^{13} \mathrm{C}$ and $0.3 \%$ for $\delta^{15} \mathrm{~N}$ (Acetanilide Standard from Thermo Electron Corporation was used for external precision). The fossil wood sample preparation for determi- 

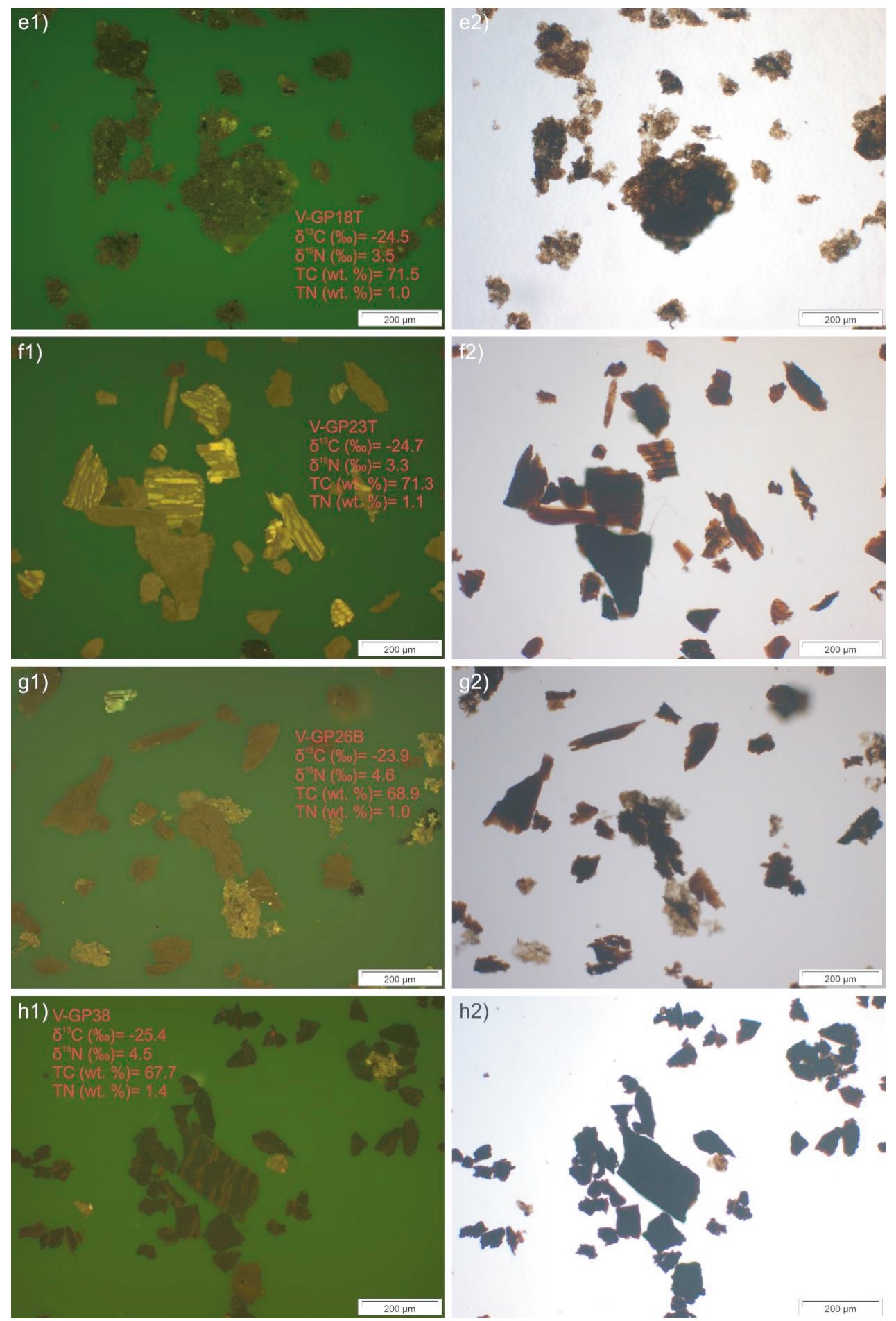

Fig. 3. (continued).

nation of TC and TN data was not performed according ASTM or ISO standards for a sample preparation for ultimate coal analysis; hence, a comparison with previously published data is difficult. However, as our samples were air-dried and the inorganic matter (minerals) was removed prior to analysis, we consider that our data is comparable to those of coal ultimate analyses reported as being air dry-ash free. 

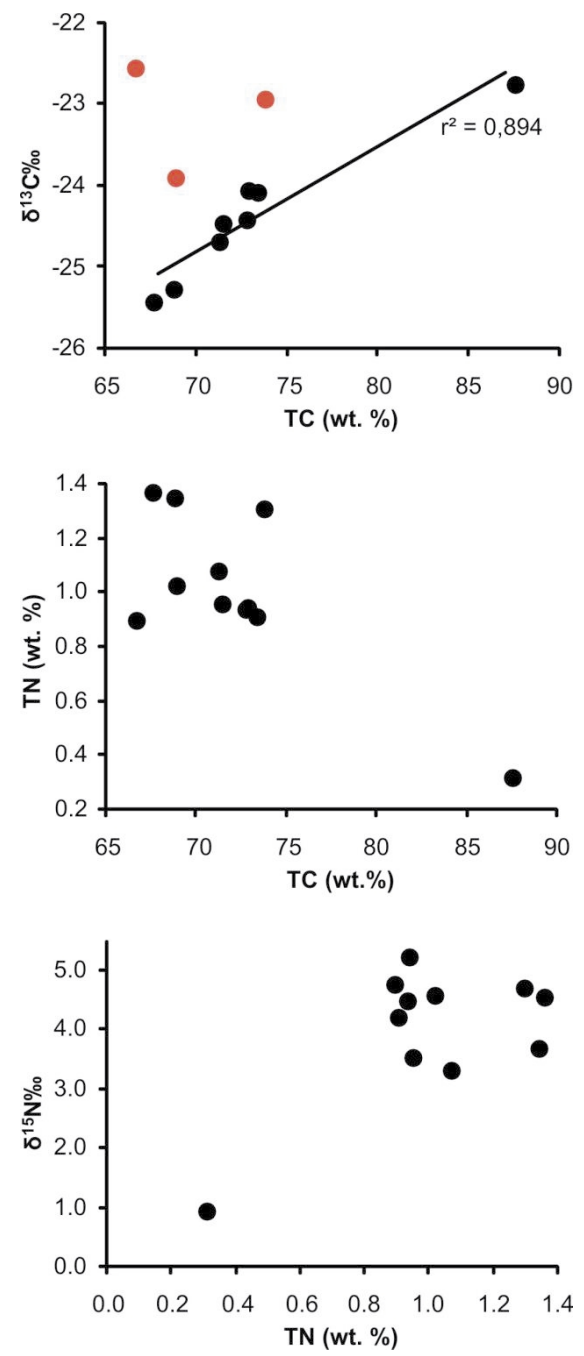

Fig. 4. Cross plots for $\delta^{13} C$ vs. TC, TN vs. TC, and $\delta^{15} N$ vs. TN of the fossil wood samples from the Polvoeira Member (Late Sinemurian) at S. Pedro de Moel (Lusitanian Basin, Portugal). The samples represented in red were not included in the regression line calculation.

\section{RESULTS}

The stratigraphic position, lithological matrix, and geochemical data of the studied samples are presented in Table 1. The hand-specimen samples are all black in color, dull, and tend to break in blocks. Lamination and striates are poorly marked, but are sometimes observed. In terms of general macroscopic aspects, sample V-GP38 exhibits the most differences as it tends to be more lustrous and breaks in a more brittle way compared to others.

Observations using TWL and FM reveal the detection of large compositional variations (palynofacies descriptions) and the preservation of fossil wood (Fig. 3). Using TWL, the specimens of fossil wood varies from opaque to translucent, although with different degrees of opacity. The optical data shows that particles are similar to those termed as phytoclasts (Bostick, 1971) in palynofacies studies (e.g., Mendonça Filho et al., 2011) which, according to Tyson (1995), are derived from the lignified parts of terrestrial plants. In samples VOU224+0.3 (Fig. 2) and V-GP2T, although particles of fossil wood are visible, the particle assemblages include high amounts of AOM, interpreted as probably being of a wood origin (Figs. 3(b) and (c)). In a few samples, palynomorphs or the AOM of marine origin are observed (e.g., Figs. 3(a), (b), (c) and (g)) (see, for example, Tyson, 1995; Mendonça Filho et al., 2011; Sawada et al., 2012 for a detailed description). It is possible to observe that the wood particles present both fluorescent and nonfluorescent particles in all the samples (e.g., Fig. 3(d)) using FM. Fluorescence intensity varies between orangebrown (Fig. 3(f1)) and dark brown (Fig. 3(h1)). Sample V-GP23T presents a high amount of resins (Fig. 3(f)). Most of these features are also seen in kerogen from rock samples of the same stratigraphic interval (e.g., Poças Ribeiro et al., 2013).

TC and TN contents vary from 66.7 to 87.6 and 0.3 to 1.4 wt. $\%$, respectively (Table 1 ). The $\mathrm{C} / \mathrm{N}$ ratio (determined from wt. \% data in Table 1) varies from 50 to 280 , with an average of 87 . The $\delta^{13} \mathrm{C}$ ranges from -25.4 to $-22.6 \%$, which is in good agreement with previously published data for terrestrial organic material (e.g., Gröcke, 2002) (Table 1). The $\delta^{15} \mathrm{~N}$ varies from 0.9 to $5.2 \%$ (Table 1). Although the entire dataset presents a large scatter $\left(r^{2}\right.$ $=0.20$, linear correlation), if we exclude three apparent outliers (red circles), $r^{2}$ of the TC vs. $\delta^{13} \mathrm{C}$ increases to 0.89 (linear correlation). Therefore, 8 out of the 11 samples present a significant positive correlation between TC content and $\delta^{13} \mathrm{C}$ (Fig. 4).

\section{DISCUSSION}

Optical observation of fossil wood composition and preservation bias

The original composition of the fossil wood samples is dominated by lignin, cellulose, tannins, colloidal humic gels, proteins, and lipid substances (Sýkorová et al., 2005), and is chemically and physically modified by biological activity, compaction, and thermal alteration during its geological evolution (e.g., ICCP, 1998, SuárezRuiz and Crelling, 2008).

The analysis of the fossil wood under TWL and FM allowed the discrimination of different preservation states of the particles, even within the same sample (Fig. 3). This is expressed in the wide range of components that were observed in each sample (see also, for example, Tyson, 1995; Mendonça Filho et al., 2011). Some of the main features noted using the optical observation of fos- 
sil wood, are the occurrences of apparently well preserved fossil wood (related to humification and gelification), opaque phytoclasts (oxidized and/or charcoalified) and AOM (of probable flora origin related to microbiological remineralization).

It is therefore evident that an assumption of a similar diagenetic (and even syngenetic) condition throughout the studied stratigraphic interval is not true for this case study (see Fig. 3). We found one of the main difficulties was to discover where the physical and chemical alteration processes took place, (i.e., in a terrestrial or marine environment). One of the key features of the palynofacies analyses from this study and that of Duarte et al. (2012) and Poças Ribeiro et al. (2013) is the occurrence of zygospores (Fig. 3(b1), an oval and slightly reticulated yellow fluorescence particle of about $200 \mu \mathrm{m}$ located in the center of the microphotography), which are interpreted as being derived from fresh-water green algae (e.g., Grenfell, 1995; Mendonça Filho et al., 2011). This suggests that at least a part of the diagenetic evolution of some of the studied fossil wood may have occurred in fluvial/swap/lacustrine/ lagoonal environments, and then remobilized to be incorporated in the nearby hemipelagic depositional setting.

\section{Elemental and isotopic data}

Carbon and nitrogen elemental data are usually expressed as a $\mathrm{C} / \mathrm{N}$ ratio, and are regarded as an indicator of source, nutritional value or the degree of organic matter alteration (e.g., Tyson, 1995). It has been observed that buried plant material has a lower $\mathrm{C} / \mathrm{N}$ ratio than fresh material, and that aerobic or anaerobic conditions cause an increase or decrease of this ratio, respectively (Gröcke, 2002 and references therein). Compared to modern fresh wood ( $\mathrm{C} / \mathrm{N}$ ratios from 250 to 1340 ), our data have lower $\mathrm{C} / \mathrm{N}$ ratios. Although we are aware of the many problems involved in the use of $\mathrm{C} / \mathrm{N}$ dating (including the possible methodological bias referred to above in Section "Materials and Methods" regarding sample preparation and ultimate coal analysis), our ratios obtained are perfectly compatible with those from ancient (buried) terrestrial organic matter presented in other studies (see Tyson, 1995, table 22.1).

The main factors controlling the amount of $\delta^{13} \mathrm{C}$ in fossil wood are the types of preserved plant tissues, taxonomic affinity, growing environment and chemical composition (e.g., Feng and Epstein, 1995; Loader et al., 2003; Poole et al., 2004, 2006; Preston et al., 2006; Harlow et al., 2006; Bechtel et al., 2007; Galle et al., 2010). Such factors pose many considerations when interpreting obtained data (e.g., Yans et al., 2010). For example, Gröcke (1998) suggested that wood diagenesis in different lithological contexts would lead to a negative correlation of $\delta^{13} \mathrm{C}$ with C, whereas Schleser et al. (1999) suggested that in more advanced stages of thermal degradation, the initial depletion of ${ }^{13} \mathrm{C}$ is overprinted by the loss of certain compounds (e.g., volatiles). During microbial activity, thermal degradation and coalification $\delta^{13} \mathrm{C}$ is expected to increase (Teichmüller and Teichmüller, 1979; Bechtel et al., 2001). In addition, Brodie et al. (2011) demonstrated that different acid pre-treatments, residual inorganic carbon contents and the organic matter state and composition can affect the $\mathrm{C} / \mathrm{N}, \delta^{13} \mathrm{C}$, and $\delta^{15} \mathrm{~N}$ values of organic matter.

The fossil wood fragments are of Jurassic age and are derived from $\mathrm{C}_{3}$ plants. The $\delta^{13} \mathrm{C}$ of $\mathrm{C}_{3}$ plants range between -23 and $-34 \%$, with an average of approximately $-27 \%$ (e.g., Gröcke, 2002). However, based on extensive literature survey, Konh (2010) has shown that this variation can actually be much larger, and that the assumed average might be overestimated by as much as $2 \%$. We found that the observed natural variation of $\delta^{13} \mathrm{C}$ posed many problems when analyzing our data because of a similar range of variation detected in our dataset, making it impossible to predict the direction of change (i.e., increasing or decreasing) of measured $\delta^{13} \mathrm{C}$ relative to the original wood carbon isotopic composition. The apparent dissimilarity of the obtained fossil wood record with contemporaneous data obtained from shells and fossil wood (Korte and Hesselbo, 2011) suggests that the $\delta^{13} \mathrm{C}$ of the studied samples does not reflect the $\delta^{13} \mathrm{C}$ of the paleoatmosphere. The organic petrographic observations and the positive correlation between TC and $\delta^{13} \mathrm{C}$ (Figs. 3 and 4) indicate that the main processes affecting $\delta^{13} \mathrm{C}$ are those linked with biological alteration or related to early diagenesis and coalification (see the aforementioned references and discussion below). In addition, our results suggest that these processes were different through the studied stratigraphic interval or if similar, acted with different magnitudes.

The obtained $\delta^{15} \mathrm{~N}$ data is in good agreement with similar studies (e.g., Boudou et al., 1984; Gröcke et al., 1999b; Gröcke, 2002; Kanduč et al., 2005; Rimmer et al., 2006) and is characterized by high values of $\delta^{15} \mathrm{~N}$ when compared to data from modern plants. If it is true that the $\delta^{15} \mathrm{~N}$ of the atmosphere during the Jurassic was not significantly different from modern day values $\left(\delta^{15} \mathrm{~N}\right.$ approximately $0 \%$ ), the fossil wood samples are therefore enriched in ${ }^{15} \mathrm{~N}$. It is generally assumed that assimilation and uptake of nitrogen by plants does not exert a major fractioning effect, thus reflecting the isotopic signal of the atmosphere (Ostrom and Macko, 1992). However, recent studies on modern flora (e.g., Evans, 2001; Hietz et al., 2010 and references therein) show that the $\delta^{15} \mathrm{~N}$ of wood can vary, for example, due to the presence of fungal symbiotic associations, fractionation between $\mathrm{NH}_{4}{ }^{+}$ and $\mathrm{NO}_{3}{ }^{-}$during uptake and assimilation, $\mathrm{N}$ availability in soil and "open vs. closed" $\mathrm{N}$ cycle. The increase of $\delta^{15} \mathrm{~N}$ in wood has been associated to $\mathrm{N}$ fertilization and/ 
or changes in drainage patterns, which are known to increase soil $\mathrm{N}$ dynamics and thereby increase soil, leaf, and wood $\delta^{15} \mathrm{~N}$. In addition, diagenesis and coalification also have the capability to change the original $\delta^{15} \mathrm{~N}$ of fossil wood. During the initial stages of wood decomposition, the processes of mineralization (sensu Kanduč et al., 2005) and anaerobic bacteria decomposition following fungi aerobic activity are expected to occur (e.g., Bechtel et al., 2001, 2003), leaving the residual organic matter depleted in ${ }^{14} \mathrm{~N}$ (Rimmer et al., 2006). The isotopic composition is then expected to remain stable until the onset of the bituminous stage (Boudou et al., 1984). From the above, it seems most likely that the high $\delta^{15} \mathrm{~N}$ of fossil wood samples was the result of microbial activity (see Rimmer et al., 2006) during the initial stages of wood decomposition and burial. It has been suggested that gelification and humification may be microbiologically mediated (Bechtel et al., 2001, 2003; Rimmer et al., 2006).

In summary, several samples present clear evidence of being affected by several processes (e.g., microbial degradation, atmospheric oxidation) or include "exotic" compounds (e.g., resin), known to modify the isotopic signal of fossil wood. However, the comparison of the (limited) isotopic dataset with the organic petrography observations does not allow the inference of a predictable variation trend of $\delta^{13} \mathrm{C}$ or $\delta^{15} \mathrm{~N}$ (Fig. 3).

\section{CONCLUDING REMARKS}

The main results concerning the use of $\delta^{13} \mathrm{C}$ and $\delta^{15} \mathrm{~N}$ of fossil wood from the Água de Madeiros Formation at S. Pedro de Moel are summarized below:

- Organic petrography observations show that fossil wood samples include a wide variety of particles mostly related to the phytoclast group, but also including resin impregnations, palynomorphs, and/or marine amorphous organic matter. A significant positive correlation between total carbon content and $\delta^{13} \mathrm{C}$ (defined by 8 out of 11 samples) is observed, and most samples present high $\delta^{15} \mathrm{~N}$.

Optical observation of fossil wood samples and the positive correlation between TOC and $\delta^{13} \mathrm{C}$ and the high $\delta^{15} \mathrm{~N}$, suggests that the main processes affecting values of $\delta^{13} \mathrm{C}$ are linked with diagenesis (either biological or related with early diagenesis and coalification).

- The data also suggest that the processes of alteration were not similar throughout all the studied samples, invalidating one of the main assumptions when using wood isotopic data for palaeoenvironmental interpretation, (i.e., that although diagenesis has altered the original $\delta^{13} \mathrm{C}$ values, it is likely that throughout a given section all samples will have undergone similar diagenetic changes).
- Our findings warrant caution on the stable carbon isotopic studies on fossil wood. It is clear that the issues raised in this work need to be taken into account in future studies, and a more detailed diagenetic screening needs to be implemented, (for example observation under TWL and FM, determination of carbon and nitrogen and $\delta^{15} \mathrm{~N}$ ), to ensure that results produced are not biased.

Acknowledgments - This work was been financially supported by project PTDC/CTE-GIX/098968/2008_-"High resolution stratigraphy of the Lower Jurassic organic-rich marine series in the Lusitanian Basin" (FCT-Portugal and COMPETEFEDER). Ricardo L. Silva would like to thank FCT-MCE for funding through a PhD fellowship (ref: SFRH/BD/47362/2008). We wish to thank both the LAFO-UFRJ team for all their technical support with sample preparations, and Elsa Teresa Rodrigues from the IMAR-CMA (Coimbra University) for her technical support in the elemental and isotopic analyses. We also warmly acknowledge the contribution of Bas van de Schootbrugge, an anonymous referee, and Ken Sawada (Associate Editor of Geochemical Journal) for helpful comments and reviews of an earlier version of the manuscript.

\section{REFERENCES}

Azerêdo, A. C., Silva, R. L., Duarte, L. V. and Cabral, M. C. (2010) Subtidal stromatolites from the Sinemurian of the Lusitanian Basin (Portugal). Facies 56, 211-230.

Bechtel, A., Gruber, W., Sachsenhofer, R. F., Gratzer, R. and Püttmann, W. (2001) Organic geochemical and stable carbon isotopic investigation of coals formed in low-lying and raised mires within the Eastern Alps (Austria). Org. Geochem. 32, 1289-1310.

Bechtel, A., Sachsenhofer, S. F., Markic, M., Gratzer, R., Lücke, A. and Püttmann, W. (2003) Paleoenvironmental implications from biomarker and stable isotope investigations on the Pliocene Velenje lignite seam (Slovenia). Org. Geochem. 34, 1277-1298.

Bechtel, A., Widera, M., Sachsenhofer, R. F., Gratzer, R., Lücke, A. and Woszczyk, M. (2007) Biomarker and stable carbon isotope systematics of fossil wood from the second Lusatian lignite seam of the Lubstów deposit (Poland). Org. Geochem. 38, 1850-1864.

Bechtel, A., Gratzer, R., Sachsenhofer, R. F., Gusterhuber, J., Lücke, A. and Püttmann, W. (2008) Biomarker and carbon isotope variation in coal and fossil wood of Central Europe through the Cenozoic. Palaeogeogr. Palaeoclimatol. Palaeoecol. 262, 166-175.

Bostick, N. H. (1971) Thermal Alteration of clastic organic matter as an indicator of contact and burial metamorphism in sedimentary rocks. Geoscience and Man 3, 83-92.

Boudou, J.-P., Mariotti, A. and Oudin, J.-L. (1984) Unexpected enrichment of nitrogen during the diagenetic evolution of sedimentary organic matter. Fuel 63, 1508-1510.

Brodie, C. R., Casford, J. S. L., Lloyd, J. M., Leng, M. J., Heaton, T. H. E., Kendrick, C. P. and Zong, Y. (2011) Evidence for bias in $\mathrm{C} / \mathrm{N}, \delta^{13} \mathrm{C}$ and $\delta^{15} \mathrm{~N}$ values of bulk organic matter, and on environmental interpretation, from a lake 
sedimentary sequence by pre-analysis acid treatment methods. Quaternary Sci. Rev. 30, 3076-3087.

Comas-Rengifo, M. J., Duarte, L. V., Goy, A., Paredes, R. and Silva, R. L. (2013) El Sinemuriense Superior (cronozonas Oxynotum y Raricostatum) en la región de S. Pedro de Moel (Cuenca Lusitánica, Portugal). Fácies carbonatadas ricas em matéria orgânica do Jurássico da Bacia Lusitânica. Novos contributos paleontológicos, sedimentológicos $e$ geoquímicos (Duarte, L. V., Silva, R. L. and Azerêdo, A. C., eds.), 15-19, Com. Geol. 100 (S1) (in Spanish with English abstract).

Czimczik, C. I., Preston, C. M., Schmidt, M. W. I., Werner, R. A. and Schulze, E.-D. (2002) Effects of charring on mass, organic carbon, and stable carbon isotope composition of wood. Org. Geochem. 33, 1207-1223.

Diefendorf, A. F., Mueller, K. E., Wing, S. L., Koch, P. L. and Freeman, H. K. (2010) Global patterns in leaf ${ }^{13} \mathrm{C}$ discrimination and implications for studies of past and future climate. PNAS 107, 5738-5743.

Duarte, L. V. and Soares, A. F. (2002) Litostratigrafia das séries margo-calcárias do Jurássico Inferior da Bacia Lusitânica (Portugal). Com. Inst. Geol. Min. 89, 135-154.

Duarte, L. V., Silva, R. L., Duarte, C. B., Azerêdo, A. C. and Comas-Rengifo, M. J. (2008) Litostratigrafia do Jurássico Inferior da região de $\mathrm{S}$. Pedro de Moel (Bacia Lusitânica). A Terra, Conflitos e Ordem. Homenagem ao Professor Ferreira Soares (Callapez, P. M., Rocha, R. B., Marques, J. F., Cunha, L. S. and Dinis. P. M., eds.), 175-185, Museu Lab. Mineral. Geol. Univ. Coimbra (in Portuguese).

Duarte, L. V., Silva, R. L., Oliveira, L. C. V., Comas-Rengifo, M. J. and Silva, F. (2010) Organic-rich facies in the Sinemurian and Pliensbachian of the Lusitanian Basin, Portugal: Total organic carbon distribution and relation to transgressive-regressive facies cycles. Geol. Acta 8, 325-340.

Duarte, L. V., Silva, R. L., Mendonça Filho, J. G., Poças Ribeiro, N. and Chagas, R. B. A. (2012) High-resolution stratigraphy, Palynofacies and source rock potential of the Água de Madeiros Formation (Upper Sinemurian) of the Lusitanian Basin, Portugal. J. Petrol. Geol. 35, 105-126.

Evans, R. D. (2001) Physiological mechanisms influencing plant nitrogen isotope composition. Trends Plant Sci. 3, 121-126.

Feng, X. and Epstein, S. (1995) Carbon isotopes of trees from arid environments and implications for reconstructing atmospheric $\mathrm{CO}_{2}$ concentration. Geochim. Cosmochim. Acta 59, 2599-2608.

Galle, A., Esper, J., Feller, U., Ribas-Carbo, M. and Fonti, P. (2010) Responses of wood anatomy and carbon isotope composition of Quercus pubescens saplings subjected to two consecutive years of summer drought. Ann. Forest Sci. 67, 809-817.

Grenfell, H. R. (1995) Probable fossil zygnematacean algal spore genera. Rev. Palaeobot. Palyno. 84, 201-220.

Gröcke, D. R. (1998) Carbon-isotope analyses of fossil plants as a chemostratigraphic and palaeoenvironmental tool. Lethaia 31, 1-13.

Gröcke, D. R. (2002) The carbon isotope composition of ancient $\mathrm{CO}_{2}$ based on higher-plant organic matter. Phil. Trans. R. Soc. Lond. A 360, 633-658.

Gröcke, D. R., Hesselbo, S. P. and Jenkyns, H. C. (1999a)
Carbon-isotope composition of Lower Cretaceous fossil wood: Ocean-atmosphere chemistry and relation to sea-level change. Geology 27, 155-158.

Gröcke, D. R., Hesselbo, S. P., Jenkyns, H. C., Taylor, G., Robinson, S. A. and Schöffel, H.-J. (1999b) Stable isotope and $\mathrm{C} / \mathrm{N}$ ratios of fossil wood from the Mesozoic: Insights into ocean-atmosphere links. Ninth Annual V.M. Goldschmidt Conference, Cambridge, U.S.A., p. 1.

Harlow, B. A., Marshall, J. D. and Robinson, A. P. (2006) A multi-species comparison of ${ }^{13} \mathrm{C}$ from whole wood, extractive-free wood and holocellulose. Tree Physiol., 26, 767-774.

Hasegawa, T. (1997) Cenomanian-Turonian carbon isotope events recorded in terrestrial organic matter from northern Japan. Palaeogeogr. Palaeoclimatol. Palaeoecol. 130, 251273.

Hesselbo, S. P. and Pieńkowski, G. (2011) Stepwise atmospheric carbon-isotope excursion during the Toarcian Oceanic Anoxic Event (Early Jurassic, Polish Basin). Earth Planet. Sci. Lett. 301, 365-372.

Hesselbo, S. P., Jenkyns, H. C., Duarte, L. V. and Oliveira, L. C. V. (2007) Carbon-isotope record of the Early Jurassic (Toarcian) Oceanic Anoxic Event from fossil wood and marine carbonate (Lusitanian Basin, Portugal). Earth Planet. Sci. Lett. 253, 455-470.

Hietz, P., Dünisch, O. and Wanek, W. (2010) Long-term trends in nitrogen isotope composition and nitrogen concentration in Brazilian rainforest trees suggest changes in nitrogen cycle. Environ. Sci. Technol. 44, 1191-1196.

ICCP (International Committee for Coal and Organic Petrology) (1998) The new vitrinite classification (ICCP System 1994). Fuel 77, 349-358.

Kanduč, T., Markič, M. and Pezdič, J. (2005) Stable isotope geochemistry of different lithotypes of the Velenje lignite (Slovenia). Geologija 48, 83-95.

Konh, M. J. (2010) Carbon isotope compositions of terrestrial $\mathrm{C}_{3}$ plants as indicators of (paleo)ecology and (paleo)climate. PNAS 107, 19691-19695.

Korte, C. and Hesselbo, S. P. (2011) Shallow marine carbon and oxygen isotope and elemental records indicate icehousegreenhouse cycles during the Early Jurassic. Paleoceanography 26, PA4219.

Loader, N. J., Robertson, I. and McCarroll, D. (2003) Comparison of stable carbon isotope ratios in the whole wood, cellulose and lignin of oak tree-rings. Palaeogeogr. Palaeoclimatol. Palaeoecol. 196, 395-407.

Mendonça Filho, J. G., Menezes, T. R. and Mendonça, J. O. (2011) Chapter 5: Organic composition (palynofacies analysis). ICCP Training Course on Dispersed Organic Matter (Flores, D. and Marques, M., eds.), 33-81, International Committee for Coal and Organic Petrology.

Ostrom, N. E. and Macko, S. A. (1992) Sources, cycling, and distribution of water column particulate and sedimentary organic matter in northern Newfoundland fjords and bays: a stable isotope study. Organic Matter: Productivity, Accumulation, and Preservation in Recent and Ancient Sediments (Whelan, J. and Farrington, J. W., eds.), 55-81, Columbia University Press.

Poças Ribeiro, N., Mendonça Filho, J. G., Duarte, L. V., Silva, 
R. L., Mendonça, J. O. and Silva, T. F. (2013) Palynofacies and Organic Geochemistry of the Sinemurian carbonate deposits in the western Lusitanian Basin (Portugal): Coimbra and Água de Madeiros Formations. International Journal of Coal Geology. Int. J. Coal Geol. 111, 37-52.

Poole, I., van Bergen, P. F., Kool, J., Schouten, S. and Cantrill, D. J. (2004) Molecular isotopic heterogeneity of fossil organic matter: implications for $\delta^{13} \mathrm{C}_{\text {biomass }}$ and $\delta^{13} \mathrm{C}$ palaeoatmosphere proxies. Org. Geochem. 35, 1261-1274.

Poole, I., Dolezych, M., Kool, J., van der Burgh, J. and van Bergen, P. F. (2006) Do stable carbon isotopes of brown coal woods record changes in Lower Miocene palaeoecology? Palaeogeogr. Palaeoclimatol. Palaeoecol. 236, 345-354.

Preston, C. M., Trofymow, J. A. and Flanagan, L. B. (2006) Decomposition, $\delta^{13} \mathrm{C}$, and the "lignin paradox". Can. J. Soil Sci. 86, 235-245.

Rimmer, S. M., Rowe, H. D., Taulbee, D. N. and Hower, J. C. (2006) Influence of maceral content on $\delta^{13} \mathrm{C}$ and $\delta^{15} \mathrm{~N}$ in a Middle Pennsylvanian coal. Chem. Geol. 225, 77-90.

Robinson, S. A. and Hesselbo, S. P. (2004) Fossil-wood carbon-isotope stratigraphy of the non-marine Wealden Group (Lower Cretaceous, southern England). J. Geol. Soc. 161, 133-145.

Sawada, K., Kaiho, K. and Okano, K. (2012) Kerogen morphology and geochemistry at the Permian-Triassic transition in the Meishan section, South China: Implication for paleoenvironmental variation. J. Asian Earth Sci. 54-55, 78-90.

Schleser, G. H., Frielingsdorf, J. and Blair, A. (1999) Carbon isotope behaviour in wood and cellulose during artificial aging. Chem. Geol. 158, 121-130.

Suárez-Ruiz, I. and Crelling, J. C. (eds.) (2008) Applied Coal Petrology. The Role of Petrology in Coal Utilization. Elsevier Ltd., Academic Press, 398 pp.

Sýkorová, I., Pickel, W., Christanis, K., Wolf, M., Taylor, G. H. and Flores, D. (2005) Classification of huminite-ICCP System 1994. Inter. J. Coal Geol. 62, 85-106.

Teichmüller, M. and Teichmüller, R. (1979) Diagenesis of coal (coalification). Diagenesis in Sediments and Sedimentary Rocks (Larsen, G. and Chilingar, G. V., eds.), 207-246, Elsevier.

Tyson, R. V. (1995) Sedimentary Organic Matter. Organic Facies and Palynofacies. Chapman \& Hall, 615 pp.

van Bergen, P. F. and Poole, I. (2002) Stable carbon isotopes of wood: a clue to palaeoclimate? Palaeogeogr. Palaeoclimatol. Palaeoecol. 182, 31-45.

Yans, J., Gerards, T., Gerrienne, P., Spagna, P., Dejax, J., Schnyder, J., Storme, J.-Y. and Keppens, E. (2010) Carbonisotope analysis of fossil wood and dispersed organic matter from the terrestrial Wealden facies of Hautrage (Mons Basin, Belgium). Palaeogeogr. Palaeoclimatol. Palaeoecol. 291, 85-105. 